\title{
Geophysical surveying to determine the structure and origin of the Woore Moraine, Shropshire, UK
}

\author{
Aidan A. PARKES, ${ }^{1}$ Ian G. STIMPSON, ${ }^{2}$ Richard I. WALLER ${ }^{2}$ \\ ${ }^{1}$ Parsons Brinckerhoff, Manchester Technology Centre, Manchester, UK \\ E-mail: aidan.parkes@pbworld.com \\ ${ }^{2}$ Research Institute for the Environment, Physical Sciences and Applied Mathematics, Keele University, Keele, UK
}

\begin{abstract}
The Woore Moraine, situated within the Cheshire Plain, is one of the largest glacial landforms in Britain. However, its key characteristics, internal structure and glaciological significance are poorly understood due to limited exposure of its key geological features. This paper focuses on the results of a suite of complementary geophysical techniques (ground-penetrating radar, electrical resistivity tomography and seismic refraction) that were used to image the interior structure of the moraine and help determine its origin. Geophysical imaging reveals a two-layer moraine structure comprising a thin and heterogeneous carapace of intercalated sediments overlying a core of subglacial clay-rich diamicton and proglacial sands deformed by a series of fore- and back-thrusts. These features indicate that the moraine is glaciotectonic in origin, involving initial compression of proglacial sediments against a bedrock obstruction and subsequent modification due to overriding.
\end{abstract}

\section{INTRODUCTION}

The Woore Moraine is a major glacial end moraine forming the eastern end of a larger moraine complex that stretches across the Cheshire Plain, Britain (Fig. 1), and is thought to have been emplaced by a terrestrial lobe of ice from the Irish Sea basin during the late Devensian (Boulton and Worsley, 1965). Various models have been postulated to account for the moraine's origin. These involve ice advance (Boulton and Worsley, 1965; Shotton, 1967a; Yates and Moseley, 1967), a stillstand (Shotton, 1967b; Worsley, 1991; Catt and others, 2006), ice stagnation (Paul, 1983; Goudie, 1990), overriding and subsequent modification of a pre-existing landform (Poole and Whiteman, 1961; Poole, 1966, 1968) and draping of glacial materials over a bedrock ridge (McQuillin, 1964). Attempts to identify the moraine's origin and significance have been hampered by its size and the limited information on its surface geomorphology and internal structure. In addition, the moraine has yet to be dated directly.

This paper forms part of a broader study that used a combination of geomorphological mapping, sedimentological analysis and geophysical surveying to constrain the origin of the Woore Moraine. Initial findings associated with the geomorphological mapping are reported in Parkes and others (2009). This showed that the moraine forms a broadly arcuate ridge $\sim 9 \mathrm{~km}$ long and $\sim 5 \mathrm{~km}$ wide and comprises three distinct landform assemblages. This follow-up paper focuses on the results of geophysical surveying that were used to image the internal structure of the moraine and to identify the constituent facies and large-scale structural features.

\section{METHODOLOGY}

The combined application of multiple geophysical techniques provides distinct yet complementary information about the moraine's large-scale internal structure and composition, as well as enabling determination or otherwise of the presence of near-surface bedrock (e.g. McQuillin, 1964). Geophysical techniques employed include groundpenetrating radar (GPR), electrical resistivity tomography
(ERT) and seismic refraction. Attempts at multichannel analysis of surface waves (MASW) were largely unsuccessful.

GPR surveys were undertaken using $50 \mathrm{MHz}$ antennae which provided the best compromise between depth penetration and resolution for the glacial material at Woore. GPR data were acquired using a Sensors and Software Inc. pulseEKKO $100^{\mathrm{TM}}$ system and stored on a 'Noggin' digital video logger. Common-offset profiling was used and GPR data were modelled using Reflex software. Common processing practices were followed (cf. Bennett and others, 2004; Sadura and others, 2006; Benediktsson and others, 2010), specifically start-time correction, timecutting, dewowing and automatic gain control. The radargrams were topographically corrected via application of a static time correction using elevation data acquired from both NEXTMap ${ }^{\text {TM }}$ data and a Leica differential GPS (DGPS). The signal velocity of $0.08 \mathrm{~km} \mathrm{~s}^{-1}$ obtained from reflection hyperbolae using Reflex software is consistent with unconsolidated mixed sand and clay (e.g. Bennett and others, 2004).

ERT surveys used a Campus Tigre resistivity meter connected via multi-core cable to a maximum of 64 metal electrodes. Based on similar studies across glacial landforms (e.g. Kulessa and others, 2007), an electrode spacing of $5 \mathrm{~m}$ was used to provide sufficient depth penetration to detect any potential bedrock. Image Pro 2000 software was used to manage the survey and record the data. Res2Dinv software was used for data modelling (Loke, 2000), with a leastsquares inversion algorithm (cf. Kulessa and others, 2007; Kristensen and others, 2009a,b). The resultant model was topographically corrected. Micro-resistivity data were collected for key facies exposed within shallow excavations using a Megger ground resistivity meter. Four electrodes were placed at $5 \mathrm{~cm}$ equal spacing in a Wenner array to constrain interpretation of the larger ERT surveys.

Seismic refraction data were collected using a sledgehammer source and up to 24 geophones spaced at $3 \mathrm{~m}$ intervals connected to a Geometrics Inc. Geode seismic recorder, similar to other surveys of glacial sediments (e.g. Kulessa and others, 2007; Hiemstra and others, 2008). The source was placed off both ends of the survey line $(-34.5$ 


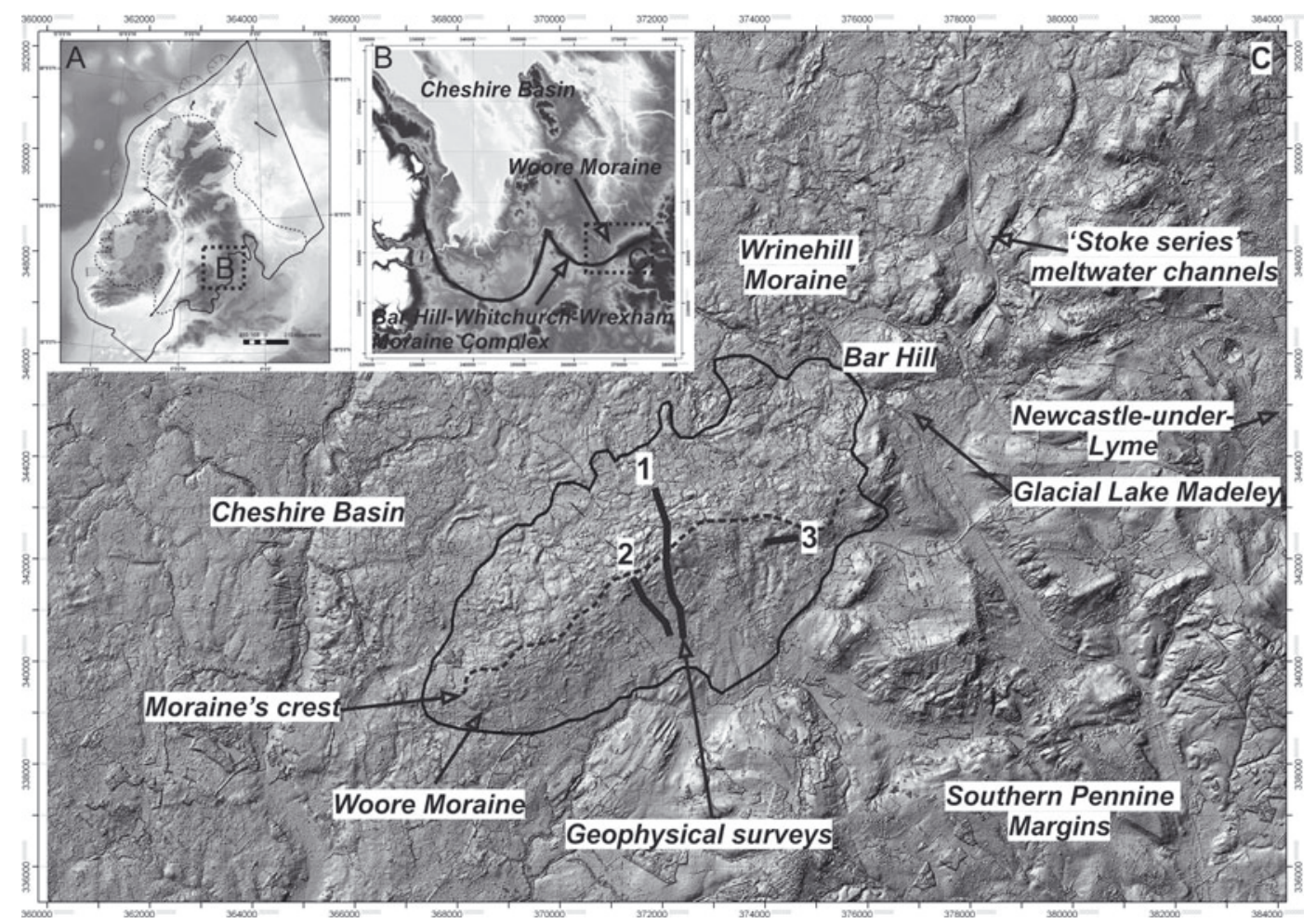

Fig. 1. Location of the Woore Moraine. (a) Two possible models of the former British-Irish ice sheet at the Last Glacial Maximum. The dashed box demarcates the Cheshire Basin (Clark and others, 2012). (b, c) These maps are NEXTMap ${ }^{\text {TM }}$ Great Britain enhanced resolution digital elevation model (DEM). (b) Topography within the Cheshire Basin. The Woore Moraine (dashed box) forms the easternmost ridge of the Bar Hill-Whitchurch-Wrexham moraine complex, a double arcuate loop of high ground adjacent to the Southern Pennine Margins. (c) Solar-shaded DEM showing the Woore Moraine and associated glacial landforms.

and $+103.5 \mathrm{~m}$ ), on both ends ( 0 and $69 \mathrm{~m}$ ) and at the survey midpoint $(34.5 \mathrm{~m})$. Seismic data were acquired with a sampling interval of $32.25 \mu \mathrm{s}$ and a record length of $0.5 \mathrm{~s}$. Refraction data were processed and analysed using SeisImager software. The plus-minus method (Hagedoorn, 1959) was used to determine the refractor depth profile.

\section{RESULTS AND INTERPRETATION}

Three transects were undertaken, with a combined total survey length of $10.5 \mathrm{~km}$ (Fig. 1). Transects 1 and 2 (Figs 2 and 3) were orientated north-south in order to provide largescale structural information for the moraine's proximal and distal flanks. Transect 3 (Fig. 4) was orientated east-west so as to profile elongated ridges orientated perpendicular to the moraine's crest.

\section{Electrical resistivity tomography}

Micro-resistivity data collected from shallow excavations constrained the interpretation of the dominant facies identified by ERT surveys. Clay/silt-dominated lithofacies at Woore generally have apparent resistivities $<50 \Omega \mathrm{m}$. Coarsergrained sand/gravel facies have higher values, with dry sands having the highest resistivities. Using a $50 \Omega \mathrm{m}$ cut-off enabled zones within the large-scale ERT surveys to be interpreted as either clay/silt-prone or sand/gravel-prone facies.

The results of the ERT surveys suggest that the Woore Moraine comprises two major units: an upper horizon with marked sedimentological heterogeneity and an underlying core that is more homogeneous in nature. The overlying unit is typically $4-6 \mathrm{~m}$ thick but reaches a maximum of $10 \mathrm{~m}$ towards the moraine crest, where very high resistivities suggest a dry sand composition. The core is dominated by low resistivity values of $<50 \Omega \mathrm{m}$ indicating a dominance of clay/silt materials. Isolated regions of higher resistivity $>60 \Omega \mathrm{m}$ indicate the localized presence of coarser material.

\section{Ground-penetrating radar}

A number of structural features have been identified using GPR. Complex discontinuous high-amplitude reflectors within the carapace represent interfaces between sediments with different physical characteristics, principally grain size (Bennett and others, 2004). These reflectors indicate rapidly alternating facies. Within the core of the moraine, isolated high-amplitude reflectors approach the surface from depth. Reflectors distal of the crest dip to the north, while those proximal of the crest dip southwards at shallow angles of $20-40^{\circ}$.

\section{Seismic refraction}

Seismic refraction data reveal a two-layer structure. An upper horizon, with a low seismic velocity of $\sim 200$ $300 \mathrm{~m} \mathrm{~s}^{-1}$, is typically $\sim 3 \mathrm{~m}$ thick on the moraine's flanks and thickens to between 10 and $20 \mathrm{~m}$ at the crest. This velocity is similar to values reported by Ismail and Sargent (2006) for mixed unconsolidated sediments consisting of both fine- and coarse-grained facies. The absence of refractions from depth within the core indicates that the upper horizon is underlain by glacial sediments a minimum of $55 \mathrm{~m}$ thick and that there is no bedrock core to the structure (cf. McQuillin, 1964). The seismic velocity of the moraine's core is $1600-2000 \mathrm{~m} \mathrm{~s}^{-1}$, which is inconsistent with Mercia Mudstone Group bedrock (cf. Francis and others, 1997). 

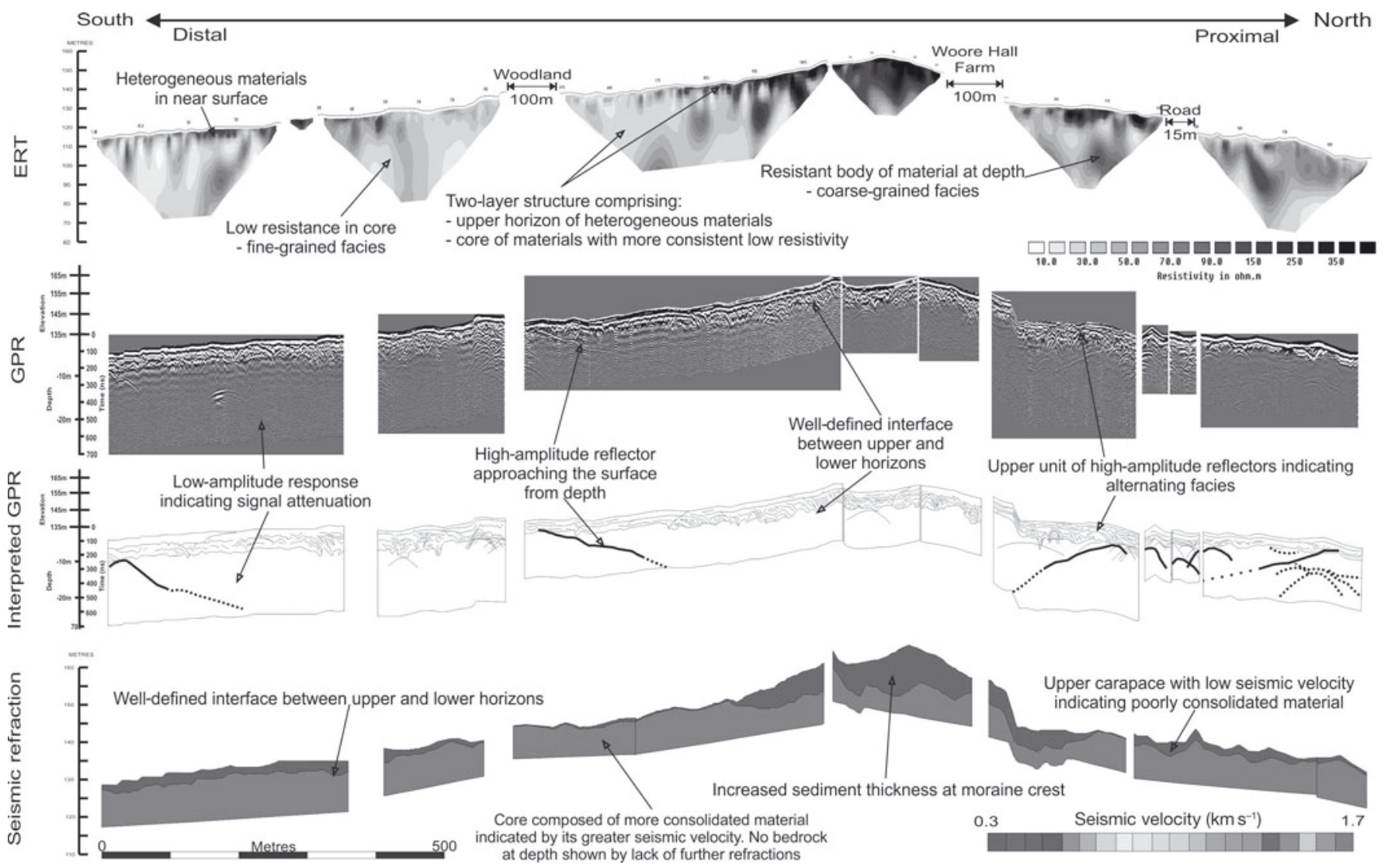

Fig. 2. Geophysical surveys conducted along transect 1 including ERT, GPR (both post-processed data and interpretation) and seismic refraction. Annotations highlight the key structural features identified.
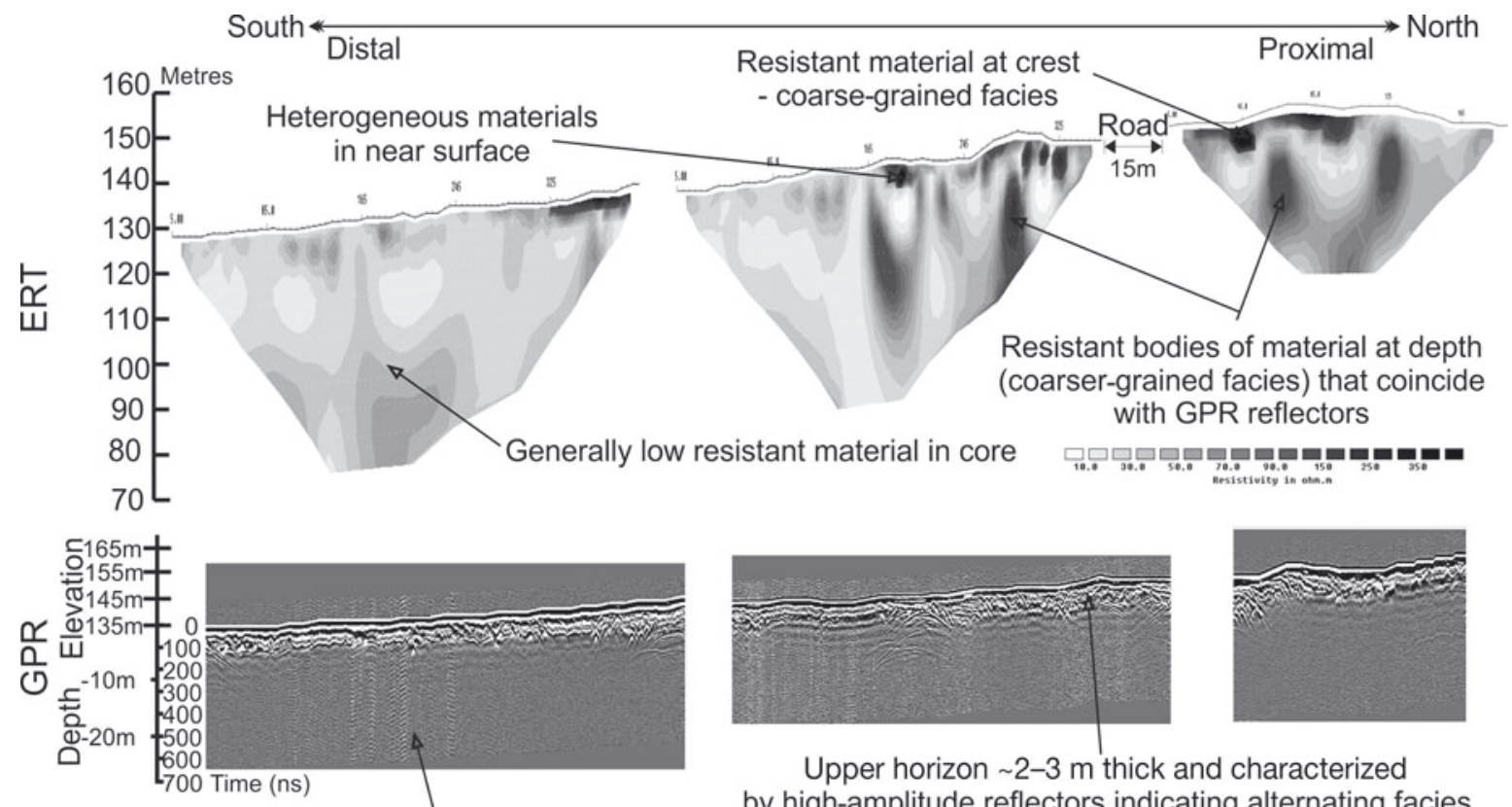

Upper horizon 2-3 m thick and characterized

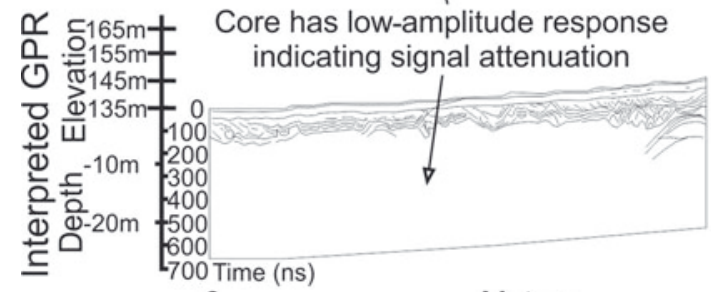
by high-amplitude reflectors indicating alternating facies
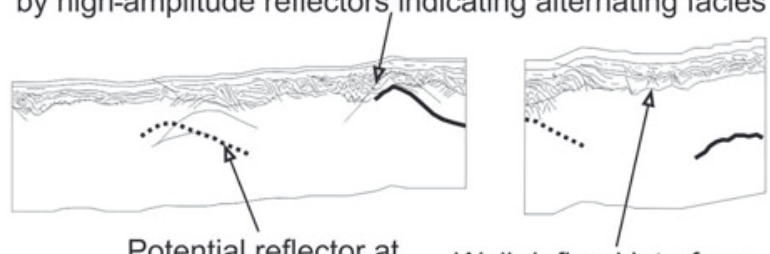

Potential reflector at Well-defined interface Metres 500

depth within core between upper \& lower units

Fig. 3. Geophysical surveys conducted along transect 2 including ERT and GPR (both post-processed data and interpretation). Annotations highlight the key structural features identified. 

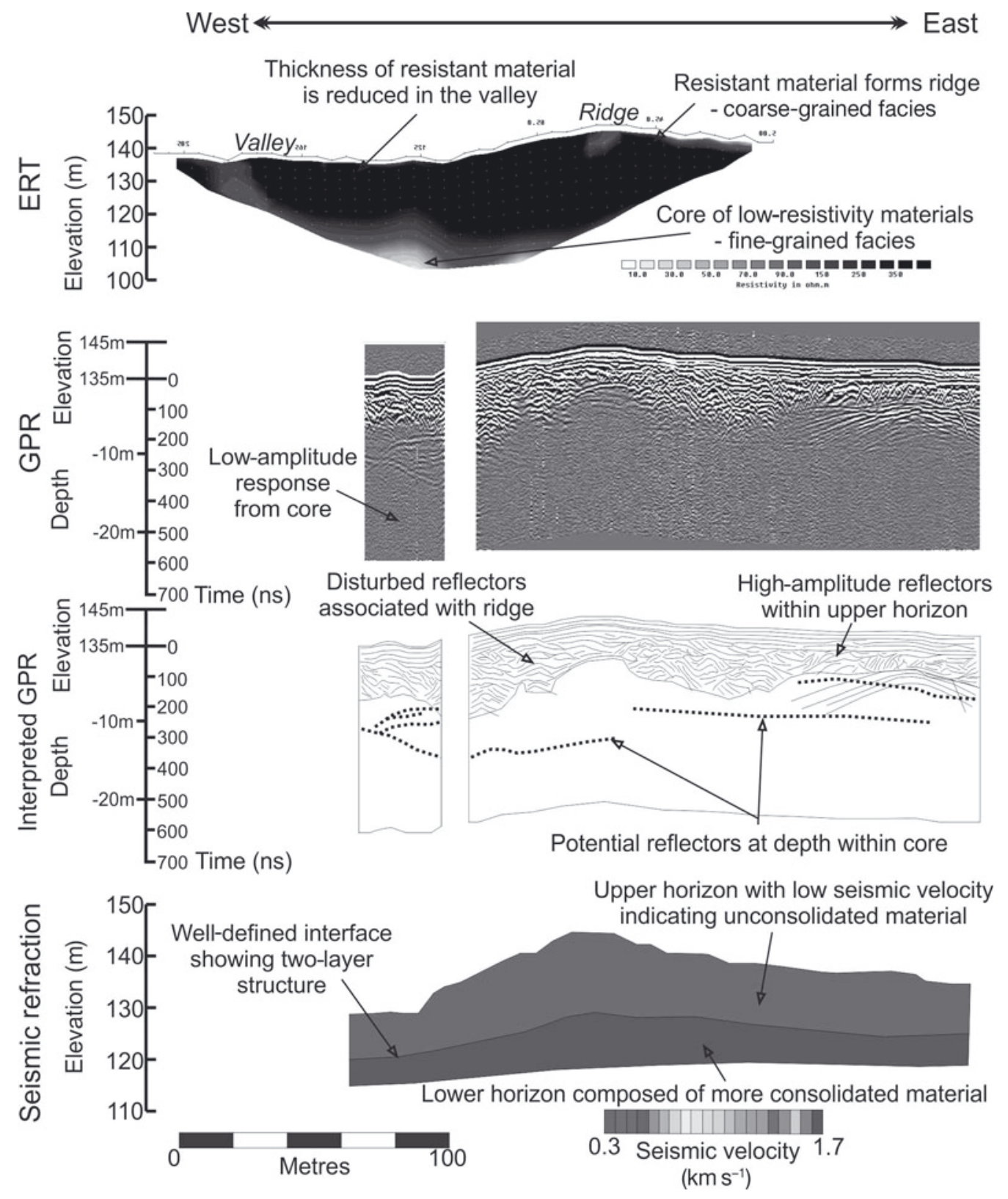

Fig. 4. Geophysical surveys conducted along transect 3 including ERT, GPR (both post-processed data and interpretation) and seismic refraction. Annotations highlight the key structural features identified.

\section{Synthesis}

The Woore Moraine's two-layer structure is similar to that observed within overridden moraines (Totten, 1969). Two units are clearly distinguishable in all geophysical datasets as they display highly contrasting geophysical properties. The two units are separated by an undulating well-defined interface, suggesting that it is an unconformity.

The upper horizon of the Woore Moraine is interpreted as a carapace of mixed glacigenic sediments. GPR highamplitude reflectors indicate rapidly changing facies exhibiting varying degrees of disturbance. The unit is present across the entire moraine and is extremely heterogeneous in nature, with ERT indicating a mixture of clay/silt and sand/ gravel facies. Sand and gravel appear to dominate the moraine's crest and the superimposed ridges, whereas the flanks of the moraine are richer in clay/silt material.

The core of the moraine has a much more consistent largescale structure than the upper carapace. ERT data indicate that it consists principally of clay/silt material, as shown by its low resistivity, typically $20-40 \Omega \mathrm{m}$, with occasional zones of higher resistivities. Similarly, GPR shows that the moraine's core is generally characterized by a lack of continuous highamplitude reflectors, indicative of high signal attenuation, a phenomenon commonly associated with fine-grained facies such as clay and silt (Schrott and Sass, 2008). Seismic velocities within the core vary between 1600 and $2000 \mathrm{~m} \mathrm{~s}^{-1}$, also consistent with consolidated clay.

Discrete reflectors within the core are interpreted as thrusts, based on a trench section excavated across the site where one of these features approaches the surface. This trench shows glacial diamicton thrust over fluvioglacial sands (Parkes, 2010). These deeper structures are northwarddipping on the south flank, fore-thrusting relative to the assumed direction of former ice-flow bulldozing, and southward-dipping, back-thrusting, on the north. These thrusts form a structural 'pop-up' feature (Park, 1997). 


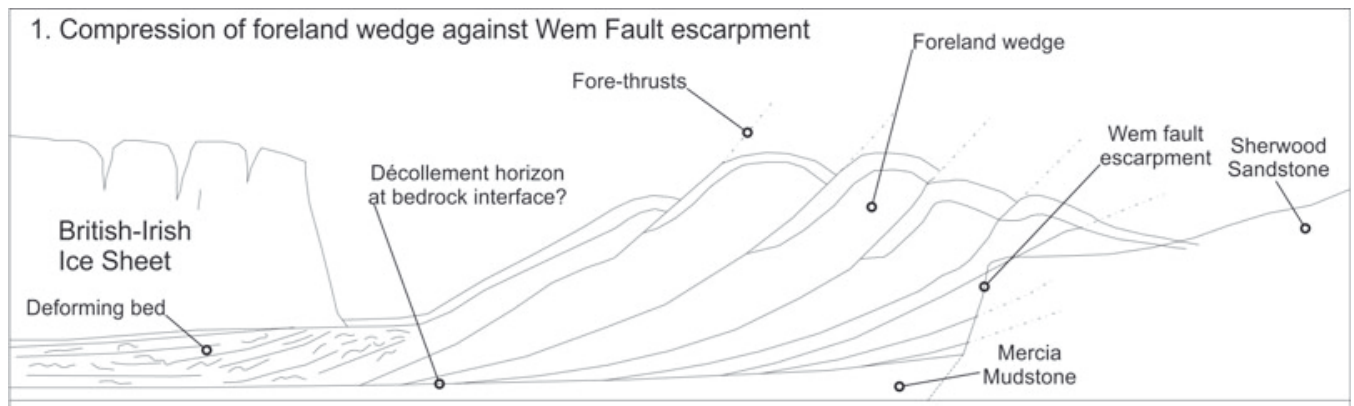

2. Propagation of back-thrusts and formation of pop-up structure
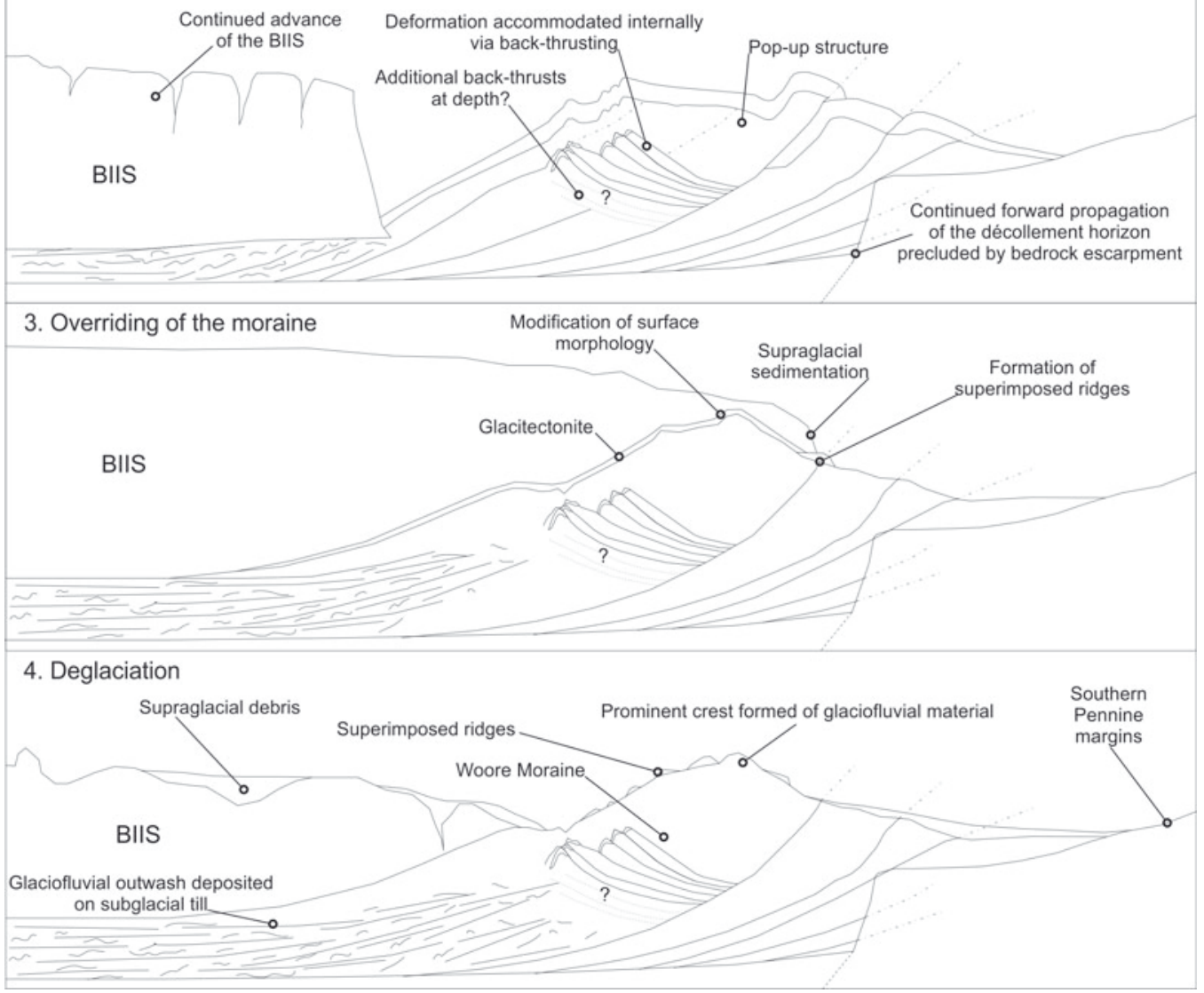

Fig. 5. Schematic cross sections illustrating the potential mechanisms of the Woore Moraine's emplacement through time. Formation relates to an advance of the British-Irish ice sheet (BIIS) that deformed pre-existing glacial sediments by fore- and back-thrusts. The moraine was subsequently modified by overriding, which developed a glaciotectonic carapace and associated superimposed landforms.

\section{DISCUSSION}

\section{Origin of the Woore Moraine}

Geophysical techniques have revealed that the Woore Moraine's internal structure and geomorphology are consistent with a polygenetic origin, specifically glaciotectonic deformation (thrusts) and overriding (overlying carapace), with input of material via accumulation processes from the nearby glacier margin (sands/gravels at the moraine's crest). This indicates that the moraine was emplaced by an active glacier lobe that underwent several phases of advance and retreat. The moraine does not show large-scale evidence for ice stagnation (cf. Paul, 1983; Goudie, 1990) or a nearsurface bedrock ridge (cf. McQuillin, 1964).

Polygenetic moraine formation reflects the dynamic nature of ice-marginal environments, which are characterized by a range of both glacial and glacially associated processes (Knight, 1999), as well as periglacial processes (Harris and others, 2004). Recent studies have recognized that even relatively simple moraine forms are likely to have been emplaced by multiple processes (e.g. Winkler and Matthews, 2010).

The Woore Moraine's structure shows that formation occurred in two distinct phases, with initial emplacement of the core and later the upper carapace separated by an erosional unconformity. The lower clay-rich part of the moraine core was initially formed as a subglacial till during the main advance of the ice lobe. As the ice sheet retreated across the Cheshire Plain, the clay-rich diamicton was covered with a layer of proglacial sands and gravels. Subsequent readvance of the ice sheet bulldozed this sequence, thickening it via fore- and back-thrusts. The moraine was then overridden, either during the same readvance or a subsequent episode. This generated the unconformity and the overlying carapace (Fig. 5).

The location of the moraine could have been influenced by the underlying geology, as its position is coincident with the subcrop of the Wem Fault that separates Triassic Mercia 
Table 1. Application of various geophysical techniques within glacial environments

Technique

Recommendations
ERT

Uses

Problems

Uses
Problems
Applicability
Uses

Seismic refraction and reflection

GPR
Mapping facies changes, associated large-scale structure and discriminating between unconsolidated materials and bedrock (e.g. Kulessa and others, 2007).

Difficult to resolve geological structures such as a faults (e.g. Kristensen and others, 2009a,b) because the technique averages the resistivity of a volume (Reynolds, 1997) and features become more difficult to resolve at depth.

Problems

Applicability
Both highly conductive and highly resistant materials (Schrott and Sass, 2008).

Identifying geological interfaces including structures. Determining internal facies and sedimentary structures. Antenna choice is a compromise between depth penetration and resolution. Signal attenuation in fines-dominated and saturated materials. Mostly coarse-grained resistive sediments.

Identifying significant interfaces and determination of depth to bedrock (e.g. Harris and others, 1997; Kulessa and others, 2007).

Unable to identify fine structure. Difficulty correlating seismic velocity to a single facies. Requires interfaces to be characterized by a significant velocity change and ideally to have simple geometries. Most environments, ideally with sub-horizontal layering.
Mudstone Group rocks to the north from Sherwood Sandstone Group to the south. The underlying geology could have led to formation of the pop-up structure in two ways. Ice-bulldozed glacigenic sediments could meet greater basal friction over the more permeable sandstones (Bennett, 2001); however, a more likely alternative is that the sediments could be buttressed by a topographical step at the fault from down-thrown less resistant mudrocks to more elevated resistant sandstones.

\section{Application of geophysical techniques within relict glacial environments}

Away from coasts, formerly glaciated regions commonly lack significant exposures. As a consequence, there has been little work in these regions, which remain poorly understood. Many studies within relict glacial environments have therefore focused on reconstructing former glaciers solely on the basis of geomorphological evidence (e.g. Clark and others, 2012). Recognition of polygenetic landforms (Harris and others, 2004; Winkler and Matthews, 2010) indicates that interpreting the origin based on geomorphological evidence alone can lead to misinterpretation of a landform's genesis and its broader significance (Evans, 2003).

Worsley (1970) advocated the application of geophysical techniques to determine the internal structure of poorly exposed glacial landforms. However, until recently, the uptake and application of geophysical techniques for investigation of relict glacial environments has been limited. GPR is most commonly used, usually as a stand-alone technique to identify structural features (Bakker, 2004). However, many geophysical techniques are available which, when used in combination, can provide a more detailed and robust model of the origin of glacial landforms. Excavations can then be used to constrain geophysical data, facilitating more accurate interpretation.

This project has shown that systematic use of multiple geophysical techniques is the best alternative to more conventional analyses when investigating a landform lacking significant surface exposures. Geophysical techniques are capable of determining the large-scale structure of a landform and facies distribution in three dimensions, even in the absence of other subsurface data (Kulessa and others, 2007). Individual techniques are associated with some limitations principally related to unfavourable ground conditions, compromise between resolution and depth of penetration, and due to difficult imaging conditions associated with rapid lateral and vertical facies changes, changing levels of porewater and compaction at depth (Table 1). Such limitations can be overcome by applying multiple techniques, as advocated by Schrott and Sass (2008). Further, the interpretation of combined geophysical data is more robust as the understanding is based on multiple sources of evidence (Kulessa and others, 2007; Hambrey and others, 2008).

Three complementary geophysical techniques were employed in this study and have demonstrated their potential in constraining the origin of the Woore Moraine. ERT mapped large-scale facies changes and these data were complemented by structural data obtained via GPR. Seismic refraction determined the depth to the interface between the carapace and underlying core and also showed that there was no bedrock ridge at shallow depths beneath the moraine's crest (cf. McQuillin, 1964).

Our experiences in deploying multiple geophysical techniques in surveying the Woore Moraine lead to a generalized approach for investigation of glacial landforms. First, geomorphological mapping enables key landforms and landform assemblages to be identified. Reconnaissance surveying allows determination of the spatial distribution and potential composition of glacial facies prior to timeconsuming extensive geophysical surveying. This enables selection of appropriate techniques and equipment, as well as determination of survey parameters such as geophone/ electrode/antenna spacing for optimum resolution and penetration of the sequences that are likely to be encountered. Where possible, the reconnaissance surveying should take place close to an exposure, borehole or excavation to calibrate the geophysical responses to the local geological materials. ERT proves to be a good tool for reconnaissance surveys, as resistivity values can be related to published data to provide an indication of the landform's composition and structure (e.g. Kristensen and others, 2009a,b).

Micro-resistivity measurements made directly in exposures constrain mapping of facies, but published resistivity ranges for specific sediments (e.g. Palacky, 1987) are suitable for more generalized interpretation of ERT data and for determining the likely sedimentary composition (Parkes and others, 2009). This in turn can assist in determining the applicability of other geophysical 
approaches, including GPR and seismic techniques. For example, mapping of extensive clay/silt-prone regions would indicate that seismic techniques, such as seismic reflection, might be more useful than GPR as fine-grained sediments cause attenuation of radar signal.

At Woore, the most useful combination of geophysical techniques was ERT and GPR because both structural features and the likely facies compositions could be determined (e.g. Hambrey and others, 2008).

\section{CONCLUSIONS}

Geophysical surveying is perhaps the most suitable alternative to conventional approaches for investigating the origin of landforms lacking exposure as it enables determination of internal facies distributions and structure. The combined application of complementary multiple geophysical techniques is essential when investigating relict glacial environments because of their complex nature. For the Woore Moraine, ERT was able to map large-scale facies changes, GPR identified structural features, and seismic refraction surveying highlighted the unconformable boundary between the moraine core and upper carapace, while demonstrating the absence of near-surface bedrock. MASW was less successful in generating stiffness profiles due to the quiet rural nature of the site.

Undertaking reconnaissance surveys prior to extensive surveying was useful to determine the potential distribution of facies within the environment. Furthermore, it allowed informed decisions to be made regarding geophysical survey parameters that govern the compromise between resolution and depth penetration. Shallow excavations and associated micro-resistivity surveys targeting features identified by the geophysics allowed the resulting interpretations to be constrained more accurately.

The approach adopted for the Woore Moraine, involving geophysical surveying using multiple complementary techniques combined with systematic landform mapping and selected excavation with sedimentological analysis of geophysical targets, works well in environments characterized by limited exposure. Such environments form a significant area of formerly glaciated regions that consequently remain little studied and poorly understood.

This study has demonstrated that the Woore Moraine is a polygenetic landform. Its internal structure consists of a moraine core comprising subglacial clay-rich diamicton deposited during the main ice advance across the Cheshire Plain, overlain by fluvioglacial outwash sands deposited during subsequent ice retreat. These are deformed by a series of fore- and back-thrusts forming a pop-up structure generated by a subsequent readvance. An upper carapace comprising more heterogeneous glacial sediments that become thicker and more sand-rich towards the moraine crest unconformably overlies the moraine core. This is associated with overriding and subglacial modification of the existing moraine during ice readvance. The close association of the Woore Moraine with the subcrop of the Wem Fault suggests a geological control on its development. The prominent fault scarp is likely to have acted as a physical obstacle to the propagation of material at the advancing margin, precluding continued forethrusting and resulting in the formation of back-thrusts, and contributing to the vertical development of the moraine as a whole.

\section{ACKNOWLEDGEMENTS}

We gratefully acknowledge the financial support of Keele University's Research Institute for the Environment, Physical Sciences and Applied Mathematics (EPSAM), which funded A.A. Parkes' studentship, as well as the logistical support and training provided by the Applied Environmental Geophysics Group. Additional funding to support the fieldwork was provided by the Royal Geographical Society (with the Institute of British Geographers) via a Postgraduate Research Award. Access to the NEXTMap ${ }^{\mathrm{TM}}$ Great Britain data was provided by the British Geological Survey. We also thank all the landowners who provided access to their land: Jane and Steve Ellsmoor of Dorrington Hall Farm, Paul Platt of Woore Hall Farm, Tony Swires of Cottage Fields Farm, Yvonne and Mark Braithwaite of Gorsey Bank Cottage and Jon Sutton of Oak Farm.

\section{REFERENCES}

Bakker MAJ (2004) The internal structure of Pleistocene push moraines: a multi-disciplinary approach with emphasis on ground penetrating radar. (PhD thesis, University of London)

Benediktsson ÍÖ, Schomacker A, Lokrantz $\mathrm{H}$ and Ingolfsson $\mathrm{O}$ (2010) The 1890 surge end moraine at Eyjabakkajökull, Iceland: a re-assessment of a classic glaciotectonic locality. Quat. Sci. Rev., 29(3-4), 84-506 (doi: 10.1016/j.quascirev.2009.10.004)

Bennett MR (2001) The morphology, structural evolution, and significance of push moraines. Earth-Sci. Rev., 53(3-4), 197-236 (doi: 10.1016/S0012-8252(00)00039-8)

Bennett MR and 9 others (2004) Sedimentary and tectonic architecture of a large push moraine: a case study from Hagafellsjökull-Eystri, Iceland. Sediment. Geol., 172(3-4), 269-292 (doi: 10.1016/j.sedgeo.2004.10.002)

Boulton GS and Worsley P (1965) Late Weichselian glaciation in the Cheshire-Shropshire Basin. Nature, 207(4998), 704-706 (doi: 10.1038/207704a0)

Catt JA and 6 others (2006) Quaternary: ice sheets and their legacy. In Brenchley PJ and Rawson PF eds. The geology of England and Wales. The Geological Society, Bath, 429-468

Clark CD, Hughes ALC, Greenwood SL, Jordan C and Sejrup HP (2012) Pattern and timing of retreat of the last British-Irish Ice Sheet. Quat. Sci. Rev., 44, 112-146 (doi: 10.1016/j.quascirev. 2010.07.019)

Evans DJA (2003) Glacial landsystems, 2nd edn. Edward Arnold, London

Francis A, Millwood Hargrave M, Mulholland P and Williams D (1997) Real and relict direct hydrocarbon indicators in the East Irish Sea Basin. In Meadows NS, Trueblood SP, Hardman M and Cowan G eds. Petroleum geology of the Irish Sea and adjacent areas. (Special Publication 124) Geological Society, London, 185-194

Goudie A (1990) The landforms of England and Wales. Blackwell, Oxford

Hagedoorn JG (1959) The plus-minus method of interpreting seismic refraction sections. Geophys. Prospect., 7(2), 158-182 (doi: 10.1111/j.1365-2478.1959.tb01460.x)

Hambrey MJ, Quincey DJ, Glasser NF, Reynolds JM, Richardson SJ and Clemmens S (2008) Sedimentological, geomorphological and dynamic context of debris-mantled glaciers, Mount Everest (Sagarmatha) region, Nepal. Quat. Sci. Rev., 27(25-26), 2361-2389 (doi: 10.1016/j.quascirev.2008.08.010)

Harris C, Williams G, Brabham P, Eaton G and McCarroll D (1997) Glaciotectonized quaternary sediments at Dinas Dinlle, Gwynedd, North Wales, and their bearing on the style of deglaciation in the Eastern Irish Sea. Quat. Sci. Rev., 16(1), 109-127 (doi: 10.1016/S0277-3791(96)00050-9) 
Harris T, Tweed FS and Knudsen O (2004) A polygenetic landform at Stígá, Öræfajökull, Southern Iceland. Geogr. Ann. A, 86(2), 143-154 (doi: 10.1111/j.0435-3676.2004.00220.x)

Hiemstra JF, Kulessa B, King EC and Ntarlagiannis D (2008) The sedimentological and geophysical anatomy of the 'Pigeon Point' drumlin in Clew Bay, Co. Mayo, Ireland. Quat. Newslett. 114, 46-51

Ismail A and Sargent S (2006) Imaging glacial sediments and underlying bedfrock in Illinois using surface wave data acquired by a land streamer. In Proceedings of the 2006 Highway Geophysics-NDE Conference, 4-7 December 2006, St Louis, Missouri, USA. (UTC Report ETT145). University Transportation Center, University of Missouri-Rolla, Rolla, MO, 286-299

Knight PG (1999) Glaciers. Stanley Thornes, Cheltenham

Kristensen L, Benn DI, Hormes A and Ottesen D (2009a) Mud aprons in front of Svalbard surge moraines: evidence of subglacial deforming layers or proglacial glaciotectonics? Geomorphology, 111(3-4), 206-221 (doi: 10.1016/j.geomorph. 2009.04.022)

Kristensen L, Juliussen H, Christiansen $\mathrm{HH}$ and Humlum O (2009b) Structure and composition of a tidewater glacier push moraine, Svalbard, revealed by DC resistivity profiling. Boreas, 38(1), 176-186 (doi: 10.1111/j.1502-3885.2008.00045.x)

Kulessa B, Clarke G, Hughes DAB and Barbour SL (2007) Anatomy and facies association of a drumlin in Co. Down, Northern Ireland, from seismic and electrical resistivity surveys. In Hambrey MJ, Christoffersen P, Glasser NF and Hubbard B eds. Glacial sedimentary processes and products. (Special Publication of the International Association of Sedimentologists 39) Blackwell, Malden, MA, 165-176

Loke MH (2000) Electrical imaging surveys for environmental and engineering studies: a practical guide to 2-D and 3-D surveys. http://www.georentals.co.uk/Lokenote.pdf

McQuillin R (1964) Geophysical investigation in a line of seismic shot holes. Bull. Geol. Surv. G. Br., 21, 197-203

Palacky GJ (1987) Resistivity characteristics of geologic targets. In Nabighian MN ed. Electromagnetic methods in applied geophysics: volume 1, theory. (Investigations in Geophysics 3) Society of Exploration Geophysicists, Tulsa, OK, 53-129

Park RG (1997) Foundations of structural geology, 3rd edn. Chapman \& Hall, London

Parkes AA (2010) A multidisciplinary study of the origin and glaciological significance of the Woore Moraine, Shropshire. (PhD thesis, Keele University)

Parkes AA, Waller RI, Knight PG, Stimpson IG, Schofield DI and Mason KT (2009) A morphological, sedimentological and geophysical investigation of the Woore Moraine, Shropshire,
England. Proc. Geol. Assoc., 120(4), 233-244 (doi: 10.1016/ j.pgeola.2009.08.011)

Paul MA (1983) The supraglacial landsystem. In Eyles N ed. Glacial geology: an introduction for engineers and earth scientists. Pergamon Press, Oxford, 71-90

Poole EG (1966) Late Weichselian glaciation in the CheshireShropshire Basin. Nature, 211(5048), 507 (doi: 10.1038/ 211507a0)

Poole EG (1968) Age of the upper boulder clay glaciation in the Midlands. Nature, 217(5134), 1137-1138 (doi: 10.1038/ 2171137a0)

Poole EG and Whiteman AJ (1961) The glacial drifts of the southern part of the Shropshire-Cheshire basin. Q. J. Geol. Soc. London, 117, 91-123

Reynolds JM (1997) An introduction to applied and environmental geophysics. Wiley, Chichester

Sadura S, Martini IP, Endres AL and Wolf K (2006) Morphology and GPR stratigraphy of a frontal part of an end moraine of the Laurentide Ice Sheet: Paris Moraine near Guelph, ON, Canada. Geomorphology, 75(1-2), 212-225 (doi: 10.1016/j.geomorph. 2005.01.014)

Schrott L and Sass O (2008) Application of field geophysics in geomorphology: advances and limitations exemplified by case studies. Geomorphology, 93(1-2), 55-73 (doi: 10.1016/ j.geomorph.2006.12.024)

Shotton FW (1967a) The problems and contributions of methods of absolute dating within the Pleistocene period. Q. J. Geol. Soc. London, 122(1-4), 357-383 (doi: 10.1144/gsjgs.122.1.0357)

Shotton FW (1967b) Age of the Irish Sea Glaciation of the Midlands. Nature, 215(5108), 1366 (doi: 10.1038/2151366a0)

Totten SM (1969) Overridden recessional moraines of north-central Ohio. Geol. Soc. Am. Bull., 80(10), 1931-1946 (doi: 10.1130/ 0016-7606(1969)8)

Winkler S and Matthews JA (2010) Observations on terminal moraine-ridge formation during recent advances of southern Norwegian glaciers. Geomorphology, 116(1-2), 87-106 (doi: 10.1016/j.geomorph.2009.10.011)

Worsley P (1970) The Cheshire-Shropshire Lowlands. In Lewis CA ed. The glaciations of Wales and adjoining regions. Longman, London, 83-106

Worsley P (1991) Glacial deposits of the lowlands between the Mersey and Severn river. In Ehlers J, Gibbard PL and Rose J eds. Glacial deposits in Great Britain and Ireland. Balkema, Rotterdam, 203-211

Yates EM and Moseley F (1967) A contribution to the glacial geomorphology of the Cheshire Plain. Trans. Pap. Inst. Br. Geogr., 42, 107-125 